\title{
Guidance on Aspects of Taxation and Filling of Annual Personal Tax Returns at SMEs, Mengwi Sub-district, Badung
}

\author{
IIDAM Manik Sastri, Luh Kade Datrini, I Gst Agung Prama Yoga, Ketut Sudarmini, \\ Ni Nym Rusmiati \\ Warmadewa University
}

\begin{abstract}
Micro Small and Medium Enterprises as well as Professional members with Taxpayer Identification Number (NPWP) in Mengwi Sub-district do not know the obligations that need to be carried out related to the NPWP ownership. Therefore the community service in Mengwi Sub-district is a form of concern for taxpayers because public awareness is a form of concern for financing national development through tax payments. Tax is the biggest and only source of state revenuein Mengwi, therefore, the government especially the Director General of Taxes provides annual tax return reports which is a measure of its compliance. The more complete the tax, the better its level of compliance, and the easier it is to educate the public in helping to finance the country. This form of community service conducted by Warmadewa University has the ability to help both parties in reducing the burden of taxpayers and assisting DGT in increasing compliance.
\end{abstract}

Keyword : NPWP, Community

\section{Pendahuluan}

Hasil kajian Pemda Badung menunjukkan UMKM terbanyak Kabupaten Badung berada di kecamatan Mengwi, yaitu sejumlah 716 UMKM. Kebanyakan usaha mereka di bidang pengolahan industri kecil dari bahan baku menjadi barang jadi. Kreativitas masyarakat untuk ikut bersaing memajukan ekonomi tidak dipungkiri, mengingat pemerintah Kabupaten Badung sangat peduli akan perkembangan UMKM di wilayahnya. Berbagai upaya telah dilakukan dalam rangka menumbuhkembangkan agar usaha UMKM menjadi berkembang sehingga akan menguranngi bahkan meniadakan pengangguran. Dari 716 UMKM yang terdapat di Kecamatan Mengwi, tidak semuanya memiliki NPWP, terbukti dari hasil servey awal menunjukkan dari operasi sisir yang dilakukan tim pengabdian menunjukkaan setengah dari UMKM tersebut masih merupakan usaha rumahan yang sederhana. Pada umumnya mereka ingin mendaftarkan diri sebagai wajib pajak apabila ada kesulitan pendanaan dan ingin meminjam uang di bank. Pihak bank akan mensyaratkan UMKM tersebut mencari NPWP. Setelah mendapatkan NPWP selanjutnya UMKM tersebut tidak mengerti kewajiban apa yang harus dilakukan atas kepemilikan NPWP tersebut. Ada yang memiliki NPWP dari 3 tahun yang lalu tanpa pernah pelaporan, ada pula beberapa NPWp baru yang masa pelaporannya 
masih aktif. Pajak merupakan sumber penerimaan negara yang paling utama dan diharapkan dapat sepenuhnya menunjang pembiayaan pembangunan nasional. Dalam lima tahun terakhir pemerintah Republik Indonesia menetapkan target penerimaan pajak dalam jumlah yang selalu tidak mudah dipenuhi oleh Direktorat Jenderal Pajak (DJP). Target yang ditentukan merupakan kebutuhan keuangan negara yang seharusnya memang diusahakan berasal dari kemampuan masyarakat. Pemungutan pajak oleh negara adalah sebuah mekanisme pemerataan pembangunan dari satu pihak kepada pihak lainnya dalam suatu negara. Negara hanya membantu mengalokasikan dengan adil kepada kebutuhan-kebutuhan yang harus didanai. Sebagai masyarakat, merupakan sebuah kewajiban berbakti kepada negara yang telah memberikan perlindungan, melalui kesadaran dalam membayar pajak.

Memenuhi target penerimaan negara adalah tanggungjawab Direktorat Jenderal Pajak, Pada tahun 2018 target penerimaan pajak di Badung khususnya dan di Bali umumnya tercapai dengan gemilang. Hal tersebut disebabkan usaha keras DJP Bali yang mengharuskan setiap Account Representatif yang membidangi wilayah tertentu melakukan operasi sisir untuk memantau apakah seluruh operasi bisnis masyarakat sudah melakukan kewajiban perpajakannya. Kalaupun sudah mmiliki NPWP apakah mereka sudah memenuhi kewajiban perpajakannya. Hal hasil tersebutlah dimana sebagian UMKM yang dikunjungi belum memiliki NPWP. NPWP seharusnya didaftarkan sendiri oleh wajib pajak dan ada pula yang diterbitkan secara jabatan oleh kantor pajak. Penerbitan secara jabatan ini disebabkan karena pihak kantor pajak menemukan ada usaha yang bekembang namun tidak memiliki NPWP. Langkah pertama pihak fiskus pasti menyarankan agar wajib pajak mendaftarkan sendiri usahanya untuk mendapatkan NPWP, selanjutnya apabila tidak ada tanggapan dalam sebulan atas saran fiskus, maka fiskus menerbitkan NPWP sendiri tanpa permintaan wajib pajak. Selanjutnya wajib pajak harus mempertanggungjawabkan kepemilikan NPWP tersebut setiap bulan bila memiliki usaha dan setiap tahun bila sebagai karyawan. Sehingga semua wajib pajak diharapkan patuh terhadap perundang-undangan perpajakan.

Wajib pajak patuh adalah wajib pajak yang memenuhi persyaratan sebagai berikut:

a. Tepat waktu dalam penyampaian surat pemberitahuan.

b. Tidak mempunyai tunggakan pajak untuk semua jenis pajak, kecuali tunggakan pajak yang telah memperoleh ijin mengangsur atau menunda pembayaran pajak.

c. Laporan keuangan diaudit oleh Akuntan Publik atau lembaga pengawasan keuangan pemerintah dengan pendapat wajar tanpa pengecualian selama 3 (tiga) tahun berturut-turut.

d. Tidak pernah dipidana karena melakukan tindak pidana di bidang perpajakan berdasarkan putusan pengadilan yanng telah mempunyai kekuatan hukum tetap dalam jangka waktu 5 (lima) tahun terakhir

Dalam perpajakan, aturan yang berlaku adalah Undang-Undang Perpajakan. Kepatuhan Wajib Pajak, merupakan kepatuhan seseorang terhadap peraturan atau Undang-Undang Perpajakan. Kepatuhan Wajib Pajak merupakan pemenuhan kewajiban yang dilakukan oleh pembayar pajak dalam rangka memberikan kontribusi bagi pembangunan negara yang diharapkan dalam pemenuhannya dilakukan secara sukarela. Kepatuhan Wajib Pajak menjadi aspek penting mengingat sistem perpajakan di Indonesia menganut self assessment system dimana di dalam prosesnya mutlak memberikan kepercayaan kepada Wajib Pajak untuk menghitung, membayar dan melaporkan kewajibannya.

Penyebab wajib pajak tidak patuh bervariasi, sebab utama adalah penghasilan yang diperoleh wajib pajak yang utama ditujukan untuk memenuhi kebutuhan hidupnya. Timbulnya konflik antara kepentingan diri sendiri dan kepentingan negara. Sebab lain adalah wajib pajak kurang sadar akan kewajiban bernegara, tidak patuh pada aturan dan kurang menghargai hukum, tingginya tarif pajak dan kondisi lingkungan sekitar. 
Dalam moderenisasi perpajakan yang diterapkan oleh DJP tidak sepenuhnya mampu dipahami oleh masyarakat, seperti pelaporan pajak melalui media elektronik yaitu $e$ filling dan pembayaran pajak melalui $e$ billing. Masyarakat kita masih kebanyakan yang tradisional dan tidak paham terhadap sistem elektronik tersebut serta membutuhkan perangkat keras berupa laptop dan printer. Sedangkan tidak semua masyarakat wajib pajak terutama pedagang dan pealaku usaha mikro kecil dan menengah lainnya tidak pernah memegang laptop.

Pengabdian masyarakat yang dilakukan pada UMKM di Kecamatan Mengwi ini dimotivasi oleh karena banyaknya jumlah wajib pajak orang pribadi yang terdaftar di wilayah KPP Badung Utara namun belum sepenuhnya melakukan kewajiban pelaporan SPT tahunan. Pada kenyataannya masyarakat wajib pajak masih merasakan ketertekanan dalam setiap menghadapi petugas pajak yang dipanggap akan selalu mengorek keterangan yang akan menyebabkan dirinya membayar pajak. Masyarakat sebenarnya ingin melakukan pelaporan SPT tahunan namun karena keterbatasan waktu dan kekurangan pengetahuan tentang cara pelaporan menyebabkan masyarakat enggan dan melalaikan kewajibannya.

Kampus sebagai sumber pembelajaran diharapkan mampu menjembatani ketakutan dan ketidak pahaman masyarakat dalam pemenuhan kewajiban perpajakan. Dalam hal ini dosen dan mahasiswa dikerahkan untuk memberikan bantuan dalam melayani masyarakat terutama UMKM yang ada di kecamatan Mengwi Kabupaten Badung. Diharapkan masyarakat tidak ketakutan melaporkan penghasilan dan kekayaannya, mengingat yang melayani mereka bukanlah petugas pajak tetapi warga kampus yaitu dosen dan mahasiswa. Tujuan Kegiatan

Tujuan yang ingin dicapai dalam pengabdian masyarakat ini adalah membantu masyarakat wajib pajak dalam memahami kewajban perpajakannya dan melaporkan kewajiban perpajakannya melalui sistem e Filling dan E Form. Dengan pengabdian masyarakat ini diharapkan pula dapat membantu Ditjen Pajak Bali dalam upaya melakukan pelayanan pelaporan SPT tahunan orang pribadi dan badan usaha, sehingga target kepatuhan wajib pajak dapat tercapai.

\section{Hasil dan Pembahasan}

Pelaksanaan pengabdian pada masyarakat di kecamatan Mengwi ini yaitu pertama dengan memberikan ceramah tentang hak dan kewajiban sebagai warga negara dimana melekat di dalamnya kewajiban sebagai wajib pajak dan petunjuk pengisian SPT tahunan. Dilanjutkan kemudian dengan menuntun wajib pajak dalam pengisian SPT Tahunannya. Apabila ada diantara UMKM tersebut telah membawa semua perlengkapan sehubungan pelaporan SPT Tahunannya seperti jumlah omzet sebulan dan ketersediaan dana untuk pembayarannya, maka dapat dibantu penyelesaian SPT Tahunan pada hari itu juga. Apabila belum ada kesiapan perhitungan omzet, maka UMKM menentukan kapan dapat menjumpai pihak kampus untuk melakukan pelayanan pengisisan SPT Tahunan secara Masal yaitu dengan membuka stand di lingkungan kantor salah satu Koperasi yang ada di Desa Sempidi. Dipilihnya Desa Sempidi karena merupakan jumlah UMKM terbanyak di kecamatan Mengwi. Pelayanan meliputi: Pembuatan Email, Pembuatan E Fin, pembayaran dengan E Billing dan dan Pelaporan SPT tahunan melalui E Filling dan E Form

Jumlah UMKM di kabupaten Badung yaitu sebanyak 15.755 diantaranya terfokus banyak di kecamatan Mengwi, yang terkenal dengan usaha kecil masyarakat di bidang perdagangan dan industri rumah tangga. Beberapa yang ditemukan selama masa pengabdian masyarakat tersebut antara lain: 
1. Kebanyakan dari UMKM tersebut belum memiliki ijin usaha, sekaligus mereka tidak memiliki NPWP, sehingga sasaran pengabdian kepada UMKM yang memiliki NPWP namun belum melakukan pelaporan SPT tahunannya. Dari hasil penjajagan awal diketahui penyebab tidak dilakukannya pelaporan SPT karena ketidak tahuan dan tidak mengerti cara untuk masuk ke DJP online. Sehingga dari pihak Universitas Warmadewa menyertakan 2 relawan Tax Center yang sudah biasa menangani pelaporan SPT tahunan dosen dan karyawan di lingkungan Warmadewa. Sebagai pembicara dalam Ceramah aspek perpajakan UMKM dan penuntun pembuatan SPT adalah dosen perpajakan yang juga berprofesi sebagai konsultan pajak yaitu Bapak I Gusti Agung Prama Yoga.

2. Dari peserta yang hadir terutama dari kantor notaris mereka semua membawa lengkap data dan dokumen yang dibutuhkan dalam pengisisn dan pelaporan SPT tahunannya, sehingga secara bergiliran dapat dilakukan pelayanan pelaporan SPT tahunan melalui $E$ filling. Untuk wajib pajak yang berstatus kurang bayar, dilakukan pembayaran di hari kerja berikutnya dan dari pihak Warmadewa tetap menyiagakan relawan pajak sampai akhir masa pelaporan yaitu melayani pelaporan dan membantu pembayaran pajaknya ke bank persepsi.

3. Selama masa pelayanan SPT tahunan Orang Pribadi, masyarakat sepempat merasa terbantu, banyak juga pertanyaan yang diajukan terutama beberapa warga ada yang bekerja di kapal pesiar tetapi tidak pernah melakukan kewajiban perpajakan karena menganggap tidak bekerja di Indonesia. Sebelum mereka berangkat berlayar seharusnya melaporkan NPWN nya menjadi non aktif terlebih dahulu agar kewajiban di tahun yang bersangkutan di Indonesia menjadi nihil. Jika tidak memohon non efektif maka pelaporan tetap dilakukan dengan menyertakan kontrak dengan perusahaan pelayaran atau instansi lain, sehingga kewajiban pembayaran pajaknya menjadi nihil.

\section{Kesimpulan}

Berdasarkan hasil pengabdian masyarakat yang telah dilakukan disimpulkan sebagai berikut:

1. Masyarakat sebagai pelaku usaha UMKM belum mengetahui kewajiban perpajakannya sebagai pemilik usaha atau sebagai pelaku profesi

2. Kesadaran masyarakat masih rendah dalam upaya ikut membantu berpartisipasi dalam pembiayaan pembangunan nasional

3. Masyarakat masih belum menyadari bahwa pembangunan nasional dan sarana prasarana yang disediakan oleh pemerintah berasal dari pajak yang disetorkan oleh masyarakat wajib pajak.

4. Masyarakat masih cenderung menyalahkan aparat dalam ketidak tahuannya tentang hak dan kewajibannya sebagai wajib pajak.

\section{References}

[1] Abdul Halim, Icuk Rangga Bawono dan Amin Dara.(2016). Perpajakan. Konsep aplikasi, Contoh dan Studi Kasus. Edisi 2. Salemba Empat. Jakarta.

[2] Arfan Ikhsan, (2014). Perpajakan. BPFE UGM. Yogyakarta

[3] Chairil Anwar, (2013). Perpajakan. Andi Offset.Yogyakarta

[4] Mardiasmo. (2014). Perpajakan. Andi Offset. Yogyakarta 
[5] Manik Sastri IIDAM. (2016) Faktor-Faktor yang Berpengaruh terhadap Kepatuhan Wajib Pajak Pada KPP Pratama Denpasar Timur

[6] Manik Sastri IIDAM. (2017) Upaya peningkatan penerimaan pajak pasca tax amnesty pada kanwil DJP Bali, Jurnal Wicaksana Universitas Warmadewa

[7] Manik Sastri IIDAM. (2018) Uji kepatuhan wajib pajak sebelum dan setelah dilakukannya tax amnesty pada kanwil DJP Bali, Jurnal Wicaksana Universitas Warmadewa

[8] Kementrian Keuangan Republik Indonesia. Direktorat Jenderal Pajak. Direktorat Jenderal Penyuluhan Pelayanan dan Humas. (2011). Undang-Undang Perpajakan. Susunan Dalam Satu Naskah 